\title{
Chronic Administration of High Doses of Nandrolone Decanoate on the Pituitary-Gonadal Axis in Male Rats
}

\author{
Mohammad Reza Shahraki ${ }^{1, ;} ;$ Hamideh Mirshekari $^{2} ;$ Ahmad Reza Shahraki $^{3}$ \\ ${ }^{1}$ Department of Physiology, Faculty of Medicine, Zahedan University of Medical Sciences, Zahedan, IR Iran \\ ${ }_{3}^{2}$ Zahedan Health Center, Zahedan University of Medical Sciences, Zahedan, IR Iran \\ 3 Emam Ali Hospital, Zahedan University of Medical Sciences, Zahedan, IR Iran \\ ${ }^{*}$ Corresponding author: Mohammad Reza Shahraki, Department of Physiology, Faculty of Medicine, Zahedan University of Medical Sciences, Zahedan, IR Iran. Tel: +98-9153415608, \\ Fax:+98-5413414563, E-mail: m_shahrakim@zaums.ac.ir \\ Received: October 13, 2014; Revised: February 16, 2015; Accepted: May 6, 2015
}

\begin{abstract}
Background: Anabolic-androgenic steroids (AAS) are abused by athletes.
Objectives: The present study was designed to evaluate chronic administration of high doses of nandrolone decanoate (ND) on the pituitary-gonadal axis and hematological parameters in normal male rats.

Materials and Methods: Thirty Wistar-Albino male rats were divided assigned to control (C), placebo (P) and test (T) groups ( $\mathrm{n}=10)$. Group T received $15 \mathrm{mg} / \mathrm{kg}$ intramuscular (IM) ND for eight weeks. Group P received the same volume of peanut oil, but group C did not receive any agent during the trial period. At the end, animals were anesthetized, killed and blood samples collected from cervical vessels. Serum follicle stimulating hormone (FSH) and luteinizing hormone ( $\mathrm{LH})$ levels were determined by sensitive rat gonadotropins kit, using ELISA methods. Serum testosterone and hematological parameters were measured by ordinary laboratory methods. Obtained data was analyzed using SPSS 17 by ANOVA and Tukey statistical tests. Results were expressed as Mean \pm SD. Statistical difference considered significantly by $\mathrm{P}<0.05$.

Results: Serum testosterone, LH, FSH, weight gain, food and water intake in group T were significantly decreased compared to other groups $(\mathrm{P}<0.05)$. In addition erythrocyte, leucocytes, hemoglobin and hematocrit in group $\mathrm{T}$ were significantly increased compared to those of other groups $(\mathrm{P}<0.05)$.

Conclusions: Chronic administration of high doses of ND can alter serum FSH, LH and testosterone and hematological parameters in male rats.
\end{abstract}

Keywords: Nandrolone Decanoate; Testosterone; Rats

\section{Background}

Nandrolone decanoate (ND) is an anabolic-androgenic steroid (AAS) used by athletes to improve their athletic ability and muscle mass (1). Anabolic-androgen steroids had various benefits for patients with anemia (2). Administration of ND for six months could increase hemoglobin and hematocrit in anemic men (3). Chronic AAS administration may alter the melanocortin system activity and appetite and food intake in rats (4). Studies showed that chronic administration of ND induces deep changes to mental health in rats (5) and causes DNA damage in leukocytes, liver, bone marrow, brain and testicle cells in mice (6). Sex steroid hormones can have a direct performance on the pituitary, follicle stimulating hormone (FSH) and luteinizing hormone (LH) secretion (7). Androgenized female rats showed alteration in the morphometric thickness of the luminal epithelium, myometrium and perimetrium associated with infertility when treated with steroids in the pre-gestational period (8).

\section{Objectives}

Since ND is abused by athletes and youth, the aim of the present study was to evaluate the effect of high doses of ND administration on serum FSH, LH, weight gain, food and water intake and hematological parameters in male rats.

\section{Materials and Methods}

Animals: This experiment was performed on 30 WistarAlbino male rats, weighing 200-230 grams kept in Zahedan University of Medical Sciences animal house and distinctly housed in cages. The present study received institutional ethical approval from the animal research committee of Zahedan University of Medical Sciences (issued 89-2362). After a week, animals were weighed by EKb10 Japan digital balance (first weight) and divided into three groups randomly as follows; control(C), placebo (P) and test $(T)$ groups $(\mathrm{n}=10)$ :

Group T received $15 \mathrm{mg} / \mathrm{kg}$ IM, ND for eight weeks (4) daily, but group $\mathrm{P}$ received the same volume of Peanut

Copyright (C) 2015, Zahedan University of Medical Sciences. This is an open-access article distributed under the terms of the Creative Commons Attribution-NonCommercial 4.0 International License (http://creativecommons.org/licenses/by-nc/4.0/) which permits copy and redistribute the material just in noncommercial usages, provided the original work is properly cited. 
oil during the trial period. Group C did not receive any agents in experimental period.

\subsection{Drug Preparation}

ND Iran Hormone (L.P.D.I.C) was purchased from a city drugstore and sustained in the appropriate temperature.

\subsection{Collection of Blood Samples}

At the end of trial period, animals were weighted (final weight) and deeply anesthetized by diethyl ether (Merck Germany), killed and blood samples were collected from cervical vessels. At first, blood samples were collected in CBC tube (coated with EDTA) for hematological parameters measurements. Residual blood samples were collected in ordinary vials and centrifuged at 3000 rpm for 10 minutes to separate serum. Serum was removed (BH-1200 type Iran) and stored at $-70^{\circ} \mathrm{C}$ for further analyses.

\subsection{Measurements}

Serum FSH and LH were measured by sensitive rat kit
(Cusabio Biotech Co. LTD, China), using ELISA method. Serum testosterone was measured by standard laboratory (Mino bine human kit USA) methods. Hematological parameters measured by usual laboratory methods.

\subsection{Statistical Tests}

Obtained data was analyzed using SPSS 17 (IBM, New York, USA) by ANOVA and Tukey tests. Results were expressed as mean \pm SD. Statistical difference considered significant at $\mathrm{P}<0.05$.

\section{Results}

Serum Testosterone, LH and FSH levels in group T were significantly decreased compared to those of $\mathrm{C}$ and $\mathrm{P}$ groups (Table $1, \mathrm{P}<0.05$ ). Moreover, weight gain, food and water intake in group $\mathrm{T}$ were significantly decreased compared to those of $\mathrm{C}$ and $\mathrm{P}$ groups (Table 2, $\mathrm{P}$ $<0.05)$. In addition, erythrocytes, leucocytes, hemoglobin, hematocrit and platelet levels in group T were significantly increased compared to those of $\mathrm{C}$ and $\mathrm{P}$ groups (Table 2, $\mathrm{P}<0.05$ ).

\begin{tabular}{|c|c|c|c|c|}
\hline \multirow[t]{2}{*}{ Parameters } & \multicolumn{3}{|c|}{ Groups } & \multirow[t]{2}{*}{ P Value } \\
\hline & C & $\mathbf{P}$ & $\mathbf{T}$ & \\
\hline FSH, IU/L & $28.11 \pm 2.89$ & $29.19 \pm 4.73$ & $22.17 \pm 2.19^{C}$ & $\mathrm{P}<0.002$ \\
\hline LH, IU/L & $8.21 \pm 3.53$ & $9.41 \pm 1.92$ & $4.82 \pm 1.62^{\mathrm{C}}$ & $\mathrm{P}<0.001$ \\
\hline Testosterone, $\mu \mathrm{g} / \mathrm{dL}$ & $4.62 \pm 2.39$ & $5.11 \pm 1.20$ & $1.09 \pm 0.58^{\mathrm{C}}$ & $\mathrm{P}<0.02$ \\
\hline \multicolumn{5}{|c|}{$\begin{array}{l}\text { a Abbreviations: C, cotrol; FSH, follicle stimulating hormone; LH, Luteinizing hormone; P, Plasebo; and T, Test. } \\
\text { b Based on ANOVA and Tukey test, FSH, LH and testosterone values in group T were significantly decreased compared to those of C and P groups } \\
\text { c } \mathrm{P}<0.05 ; \mathrm{n}=10 \text {. }\end{array}$} \\
\hline \multirow[t]{2}{*}{ Parameters } & \multicolumn{3}{|c|}{ Groups } & \multirow[t]{2}{*}{ P Value } \\
\hline & C & $\mathbf{P}$ & $\mathbf{T}$ & \\
\hline Weight, g & $239.6 \pm 13.5$ & $237.9 \pm 11.6$ & $212.4 \pm 11.6^{\mathrm{C}}$ & $\mathrm{P}<0.001$ \\
\hline Food intake, $g$ & $15.1 \pm 1.9$ & $15.6 \pm 1.1$ & $14.1 \pm 1.3^{\mathrm{C}}$ & $\mathrm{p}<0.002$ \\
\hline Water intake, $\mathrm{mL}$ & $43.4 \pm 4.4$ & $44.6 \pm 2.3$ & $40.6 \pm 2.3^{c}$ & $\mathrm{P}<0.02$ \\
\hline Hemoglobin, gr/dL & $14.5 \pm 2.2$ & $14.82 \pm 51$ & $16.41 \pm 1.21^{\mathrm{c}}$ & $\mathrm{P}<0.03$ \\
\hline Leucocytes, cell/ $/ \mu \mathrm{L}$ & $7200 \pm 800$ & $69200 \pm 970$ & $8600 \pm 1100^{c}$ & $\mathrm{P}<0.01$ \\
\hline Erythrocyte, $\mathrm{mL} / \mu \mathrm{L}$ & $5.81 \pm 1.2$ & $5.22 \pm 1.2$ & $6.95 \pm 1.3^{\mathrm{C}}$ & $\mathrm{P}<0.01$ \\
\hline Hematocrit, \% & $43 \pm 4$ & $43 \pm 3$ & $48 \pm 4^{\mathrm{C}}$ & $\mathrm{P}<0.01$ \\
\hline Platelets, $1000 \mathrm{cell} / \mu \mathrm{L}$ & $230 \pm 34$ & $228 \pm 30$ & $320 \pm 42^{C}$ & $\mathrm{P}<0.02$ \\
\hline
\end{tabular}

a Abbreviations: C, Cotrol; P, Plasebo; and T, Test.

b Based on ANOVA and Tukey tests, weight gain, food and water intake values in group T were significantly decreased compared to those of group C, but hematological parameters were increased compared to other groups.

c $\mathrm{P}<0.05 ; \mathrm{n}=10$.

\section{Discussion}

Chronic administration of ND at high dose decreased plasma FSH, LH, testosterone, weight gain and food and water intake in male rats. In addition, erythrocytes; hemoglobin, hematocrit, Leukocyte and platelets values were increased in group T. High doses of AAS used for athletic enhancement can lead to irreversible organ damage such as reduced fertility and gynecomastia in males (9). Moreover, AAS has a high affinity for the androgen receptor in central and peripheral tissues and causes impairments in hypothalamicpituitary-gonadal axis (9). 
In addition, Kuhn CM reported that AAS affects androgen receptors and alters enzymatic aromatization of testosterone derivatives to increase its affinity to estrogen receptors (10). Our finding exposed that ND decreased serum LH and testosterone secretion in the group T. These results are the same as Alsio (11), which reported that AAS administration was probable to reduce hypothalamicpituitary-gonadal axis activity by affecting physiological feedback mechanisms. Bijlsma et al. (7) in a pilot study found that ND administration in male patients with rheumatoid arthritis caused significant decreases in serum Testosterone and FSH levels. Our findings showed that FSH value in group T was significantly deceased compared to that of other groups and it was the same as literature study (10). Oda and El-Ashmawy (12) reported that chronic administration of ND caused decrease in testes and epididymis weights, but did not show any significant changes in weight gain in normal rabbits. Our results are different with that of Oda and El-Ashmawy (12). This difference is probably due to different used animals. Our findings were in accordance with the theory that sex steroids hormones can act directly on the hypothalamus- pituitary-testis axis and resulting in selective FSH and LH secretion (8). In addition, our outcome was in agreement with that of Shokri et al. (13), which revealed that exercise training increases the amount of apoptosis in the spermatogenic cell lineage by supraphysiological dose of ND in rats. Our study revealed that weight gain, food and water intake in group $\mathrm{T}$ were significantly decreased compared to those of other groups, which is in accordance with the literature (14). Bhasin et al. (14) found that erythrocytes, hemoglobin and hematocrit were improved dose dependently in healthy men aged 18 to 50 years who received AAS and changes in levels of hemoglobin and hematocrit were related to changes in testosterone concentrations compared to those of placebo group. In the present study, erythrocyte, hemoglobin, hematocrit, leukocyte and platelets values in group T were significantly increased compared to those of other groups and confirmed by another investigation (14). This is presumably because chronic ND administration in the present study increased metabolism, serum erythropoietin concentration and stimulated hematopoiesis in bone marrow.

In conclusion, chronic administration of high doses of ND administration could alter serum FSH, LH, testosterone, weight gain, food and water intake and hematological parameters in male rats.

\section{Acknowledgements}

This study was financially supported by the Deputy Research Center of Zahedan University of Medical Sciences (project No720).

\section{Funding/Support}

This study was supported by Zahedan University of Medical Sciences and Health Services, Zahedan, IR Iran.

\section{References}

1. Hold KM, Borges CR, Wilkins DG, Rollins DE, Joseph RJ. Detection of nandrolone, testosterone, and their esters in rat and human hair samples. J Anal Toxicol.1999;23(6):416-23.

2. Chawla B, Iqbal FM, Chawla MS. Nandrolone decanoate for the treatment of erythropoietin refractory anemia: a case series. Compr Ther. 2009;35(3-4):199-203.

3. Gascon A, Belvis JJ, Berisa F, Iglesias E, Estopinan V, Teruel JL. Nandrolone decanoate is a good alternative for the treatment of anemia in elderly male patients on hemodialysis. Geriatr Nephrol Urol.1999;9(2):67-72.

4. Lindblom J, Kindlundh AM, Nyberg F, Bergstrom L, Wikberg JE. Anabolic androgenic steroid nandrolone decanoate reduces hypothalamic proopiomelanocortin mRNA levels. Brain Res. 2003;986(1-2):139-47.

5. Elfverson M, Johansson T, Zhou Q, Le Greves P, Nyberg F. Chronic administration of the anabolic androgenic steroid nandrolone alters neurosteroid action at the sigma-1 receptor but not at the sigma-2 or NMDA receptors. Neuropharmacology. 2011;61(7):1172-81.

6. do Carmo CA, Goncalves AL, Salvadori DM, Maistro EL. Nandrolone androgenic hormone presents genotoxic effects in different cells of mice. J Appl Toxicol. 2012;32(10):810-4.

7. Bijlsma JW, Duursma SA, Thijssen JH, Huber O. Influence of nandrolondecanoate on the pituitary-gonadal axis in males. Acta Endocrinol (Copenh). 1982;101(1):108-12.

8. Camargo IC, Gaspar AL, Frei F, Mesquita Sde F. [Effects of androgenic anabolic steroids on the uterus and reproductive parameters of adult female rats]. Rev Bras Ginecol Obstet. 2009;31(9):453-60.

9. Maravelias C, Dona A, Stefanidou M, Spiliopoulou C. Adverse effects of anabolic steroids in athletes. A constant threat. Toxicol Lett. 2005;158(3):167-75.

10. Kuhn CM. Anabolic steroids. Recent Prog Horm Res. 2002;57:411-34

11. Alsio J, Birgner C, Bjorkblom L, Isaksson P, Bergstrom L, Schioth $\mathrm{HB}$, et al. Impact of nandrolone decanoate on gene expression in endocrine systems related to the adverse effects of anabolic androgenic steroids. Basic Clin Pharmacol Toxicol. 2009;105(5):307-14.

12. Oda SS, El-Ashmawy IM. Adverse effects of the anabolic steroid, boldenone undecylenate, on reproductive functions of male rabbits. Int J Exp Pathol. 2012;93(3):172-8.

13. Shokri S, Aitken RJ, Abdolvahhabi M, Abolhasani F, Ghasemi FM, Kashani I, et al. Exercise and supraphysiological dose of nandrolone decanoate increase apoptosis in spermatogenic cells. Basic Clin Pharmacol Toxicol. 2010;106(4):324-30.

14. Bhasin S, Travison TG, Storer TW, Lakshman K, Kaushik M, Mazer NA, et al. Effect of testosterone supplementation with and without a dual 5alpha-reductase inhibitor on fat-free mass in men with suppressed testosterone production: a randomized controlled trial.JAMA. 2012;307(9):931-9. 